\title{
ADOPTING A LONG VIEW TO ENERGY R\&D AND GLOBAL CLIMATE CHANGE
}

\section{JJ Dooley and PJ Runci}

February 1999

Prepared for

U.S. Department of Energy

under Contract DE-AC06-76RLO 1830

Pacific Northwest National Laboratory

Operated for the U.S. Department of Energy

by Battelle Memorial Institute

\section{Battelle}

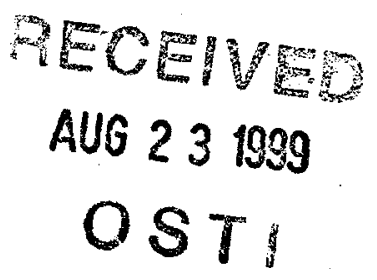




\section{DISCLAIMER}

This report was prepared as an account of work sponsored by an agency of the United States Government. Neither the United States Government nor any agency thereof, nor Battelle Memorial Institute, nor any of their employees, makes any warranty, express or implied, or assumes any legal liability or responsibility for the accuracy, completeness, or usefulness of any information, apparatus, product, or process disclosed, or represents that its use would not infringe privately owned rights. Reference herein to any specific commercial product, process, or service by trade name, trademark, manufacturer, or otherwise does not necessarily constitute or imply its endorsement, recommendation, or favoring by the United States Government or any agency thereof, or Battelle Memorial Institute. The views and opinions of authors expressed herein do not necessarily state or reflect those of the United States Government or any agency thereof.

PACIFIC NORTHWEST NATIONAL LABORATORY

operated by

BATTELLE MEMORIAL INSTITUTE

for the

UNITED STATES DEPARTMENT OF ENERGY

under Contract DE-AC06-76RLO 1830 


\section{DISCLAIMER}

Portions of this document may be illegible in electronic image products. Images are produced from the best available original document. 


\begin{abstract}
In this paper, we present findings indicative of important, ongoing changes in the energy research and development (R\&D) investment portfolios of major OECD nations. We seek to explain the drivers of these changes and discuss their implications for the world's ability to deal with future R\&D-intensive energy challenges, such as global climate change. We also consider possible implications of changes in individual countries' energy R\&D portfolios for international energy $R \& D$ collaboration among OECD countries themselves, and between OECD and developing countries. We conclude that the level of investment in energy $R \& D$ in the OECD is likely insufficient to meet the energy $R \& D$ challenges of climate change. A long-term, strategic approach would aim to broaden both the amount of resources devoted to energy $R \& D$ and the geographical scope of the global energy R\&D infrastructure. A successful strategy will account for large-scale changes in demographics and energy use over the coming decades will drive the development of indigenous energy $R \& D$ capabilities in developing countries.
\end{abstract}

KEY WORDS: Energy R\&D, Global Climate Change, Energy Technologies. 
For well over a decade, the world has enjoyed a period of cheap and abundant energy supplies. Since the oil shocks of the 1970s, a combination of factors, including technological advances, discoveries of new petroleum resources, improved energy productivity, and the creation of futures markets, has alleviated fears that the energy future would necessarily be characterized by scarcity and high prices. The 1990-91 Persian Gulf War, which caused only a brief price spike on international energy markets, ultimately bolstered optimism concerning the world's improved adeptness at managing energy crises.

Amid the general energy optimism that has persisted since the mid-1980s, government investments in energy research and development $(R \& D)$ have declined in many advanced industrial countries. To a great extent, the reduction in government commitments to energy $R \& D$ reflects the perception that energy has become a matter of lesser urgency, relative to other social priorities.

At the same time, an ideological shift in the industrialized countries toward the deregulation of key industries, such as electric and gas utilities, has placed additional pressures on R\&D investments. With the introduction of competitive forces in the energy industries and the elimination of guaranteed returns, firms' (in particular, electric and gas utilities') R\&D investments have grown smaller. Remaining $R \& D$ resources gravitate more often to lower risk, market-oriented projects than to riskier projects with more distant payoffs.

Yet, while public and private sector energy $R \& D$ investments have declined, a major new energy challenge has appeared on the horizon that will demand significant and sustained commitments to the development of new energy technologies. The long-term challenge of global climate change, and actions aimed at its mitigation, will require a transition to fuels and energy technologies that emit less carbon dioxide and other greenhouse gases-substances whose rising concentrations in the atmosphere are thought to be major contributors to global warming and related climatic changes. ${ }^{2}$ In the shorter-term, the costs associated with the reduction of greenhouse gas emissions will depend critically on the technologies that become available for deployment in the first decades of the next century. The estimated costs of greenhouse gas reduction span many orders of magnitude, with some scenarios showing costs approaching zero, assuming widely available and widely deployed advanced energy technologies. ${ }^{3}$ The challenge is made greater still by projections that global energy use is expected to grow by $75 \%$ by 2020 and that most of the new demand will be met with fossil fuels.

In December 1997, official delegations from over 150 countries met in Kyoto, Japan, where many participating countries also signed an international treaty aimed at reducing global emissions of carbon dioxide. Under the Kyoto Protocol, the major industrialized countries agreed to reduce their carbon emissions by $6-8 \%$ from their 1990 levels within the period 2008-2012. Yet the Kyoto Protocol has not been ratified by any major signatories and its prospects, in the United States especially, are dim. While governments of industrialized countries now view the climate change issue with increasing seriousness, there is still insufficient urgency surrounding the problem to precipitate major political action and new government commitments to energy R\&D.

\footnotetext{
' JJ Dooley, "Unintended Consequences: Energy R\&D in a Deregulated Market," Energy Policy (June 1998).

${ }^{2}$ See Intergovernmental Panel on Climate Change, IPCC Second Assessment: Climate Change 1995, p. 13.

${ }^{3}$ JA Edmonds, JJ Dooley, and MA Wise, "Atmospheric Stabilization: The Role of Energy Technology," in Climate Change Policy, Risk Prioritization, and US Economic Growth (Washington, DC: American Council for Capital Formation, June 1997).
} 


\section{Global Climate Change and Energy Technology: The Long View}

In addition to the political and economic aspects of the Kyoto Protocol that have hindered its adoption, questions concerning the agreement's effectiveness in combatting climate change also loom large in the minds of politicians and scientists. Such questions arise from the fact that the climate change problem is unfolding on a century-scale, yet the mitigative actions encompassed by the Kyoto Protocol are often viewed as a "quick fix" to be implemented over the short span of the coming decade. The short implementation schedule of the Kyoto Protocol essentially dictates that the world address climate change with those technologies currently available. Consequently, poor results could be purchased at high cost.

A more favorable, alternative approach to climate change would consider that continued advances in the state of the art of energy technology, which are in large part a function of energy R\&D investment levels, will expand the problem's solution set. Thus, the state of energy R\&D will also determine to a large extent the cost of attaining any stabilized "safe" atmospheric concentration of greenhouse gases over the coming century. Based on this logic, sustained energy R\&D investment must be viewed as a vital component of a century scale strategy designed both to address the problem effectively and to minimize associated costs. Considering also that the majority of growth in world energy consumption expected in the next century will occur in the developing world, an effective strategy must include provisions ensuring the participation of key developing states. Countries such as China, India, and Brazil should be encouraged and assisted to become future producers of energy $R \& D$ and energy technologies and ought not be expected to remain contented consumers of Western expertise and hardware throughout the next century.

Moreover, the motivation for major developing countries to develop indigenous energy R\&D infrastructures extends beyond climate change. Local environmental conditions, particularly air quality, is already a severe problem in many industrializing areas. The impetus for the deployment of newer and cleaner energy technologies will also grow as the levels of industrial activity and energy demand rise in developing countries.

To understand the increasingly significant role of developing countries in strategies to address climate change, it is useful to consider some anticipated global energy and economic trends. Figure 1 shows regional projections of gross domestic product (GDP) for the period 1990-2095. Most recent data show, for example, that China's economy is now less than half the size of the United States' economy. Yet if China's economic growth persist at its current rate, it will likely become one of the world's largest economies towards the middle of the next century. By the middle of the century, China might also be significantly wealthier when measured in terms of GDP per capita. These figures also show that several other countries currently regarded as "developing," and that currently lack an advanced and extensive technology R\&D infrastructure, are likely to experience significant growth in wealth during the next century.

\footnotetext{
${ }^{4}$ It is important to note that the Framework Convention on Climate Change is silent on what would be a "safe" atmospheric concentration for greenhouse gases and that these levels remain a subject of debate. The lower the "safe concentration" is judged to be the more difficult the challenge of climate change becomes and the more critical advances in energy R\&D will become.

${ }^{5}$ These data were generated from the "B2F" non-intervention scenario generated as a part of the Intergovernmental Panel on Climate Change, Working Group III's forthcoming Special Report on Emissions Scenarios (SRES). B2F is a conservative growth scenario over the course of the next century.
} 
Figure 1 Gross Domestic Product by Region

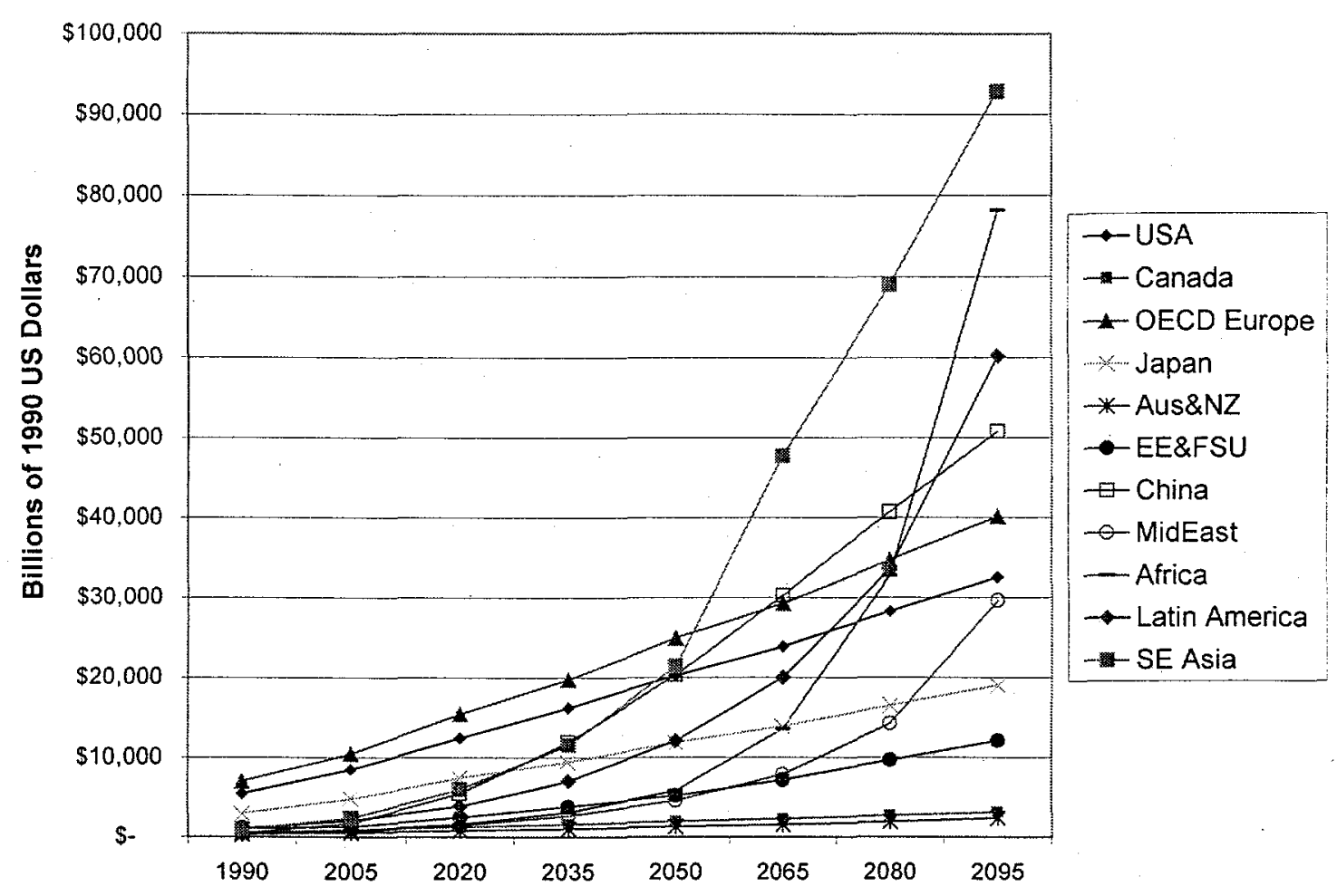

Figure 2 shows projected carbon equivalent greenhouse gas emissions over the period 1990 to 2095 for the same regions included in Figure 1. The percentage of global carbon emissions attributable to OECD countries is expected to decline rapidly--from $49 \%$ of global emissions in 1990 to less than a third of global emissions by 2035 and to less than one quarter of global emissions by the end of the next century as developing countries' energy use rises. While on the other hand, China's share of global carbon emissions, for example, is expected to grow from $12 \%$ in 1990 to some $25 \%$ by 2020 . Similarly, Southeast Asia's carbon emissions are likely to rise from under $7 \%$ in 1990 to $25 \%$ by 2065 .

The actual development trajectories that the world's regions will follow in coming decades will, of course, diverge from those projected under any modeling scenario. Nonetheless, given the momentum of demographic and economic drivers already in motion, the continued growth of developing countries' wealth and energy use should be anticipated even if the precise slopes of their growth trajectories are uncertain. That said, it is now appropriate to consider ways by which to propagate a robust and more geographically distributed global energy $R \& D$ infrastructure to ensure that sufficient resources are devoted to energy technology development worldwide to meet the climate challenge throughout the coming century. As the following section shows in some detail, trends in the national energy $R \& D$ programs of key industrialized countries argue in favor of the development of a more distributed global energy R\&D capability. 
Figure 2: Carbon Dioxide $\left(\mathrm{CO}_{2}\right)$ Emissions by Region

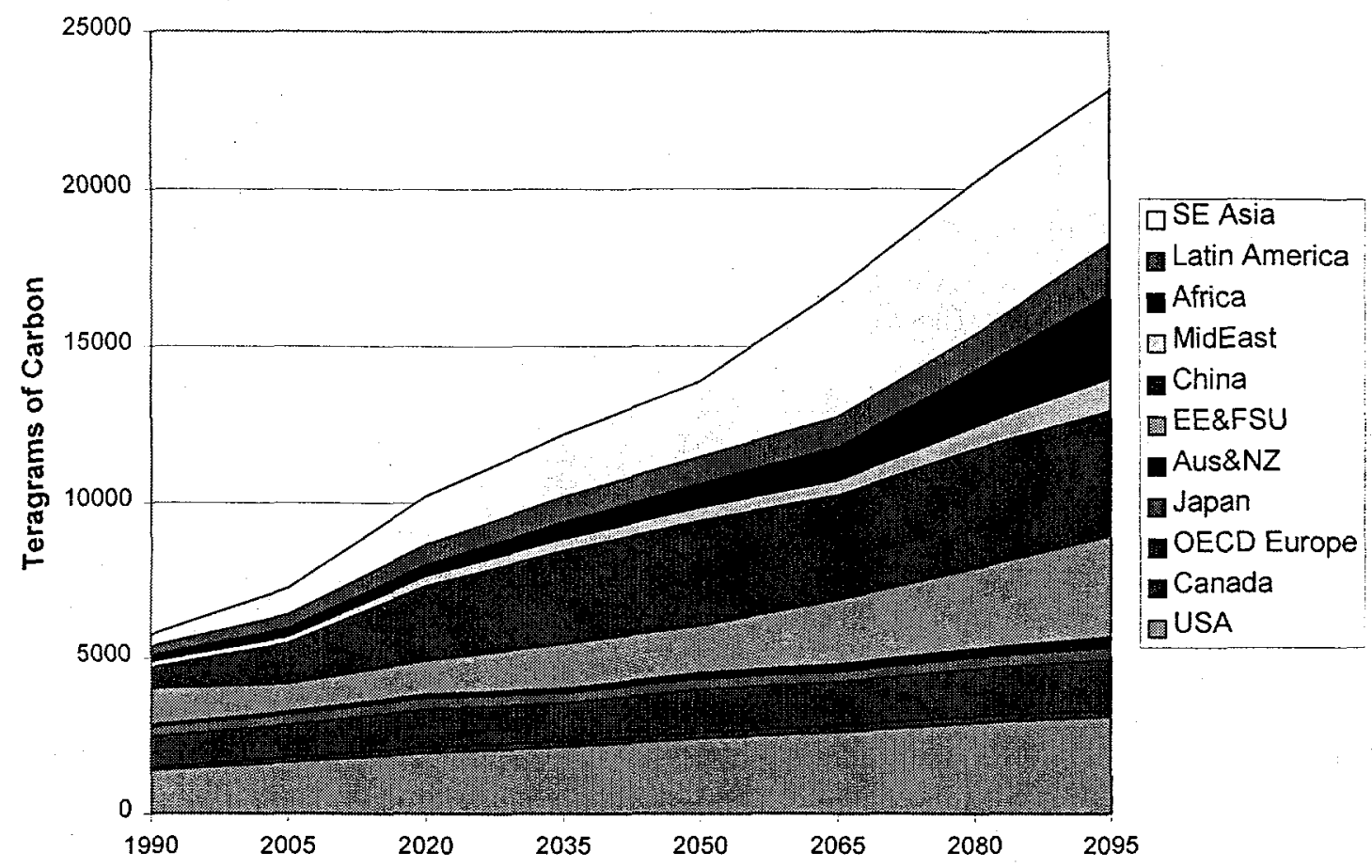

The Energy R\&D Infrastructure of Selected OECD Countries

Private Sector Energy R\&D. Describing changes in the private sector's support of energy R\&D can be difficult due to the proprietary nature of data concerning industry's R\&D support. That said, this section presents a composite sketch drawn from available information, suggesting that private sector support for energy R\&D is undergoing significant changes and downsizing. Moreover, in addition to the fact that private sector energy $R \& D$ is in rapid decline, $R \& D$ investments are being redirected from longer-term projects that might be viewed as having a higher value from a public goods perspective. Instead, investments are directed to a greater extent to meet the near-term proprietary needs of private sector energy R\&D companies operating in competitive markets. This reorientation has major implications from the standpoint of public policy; for example, a widening energy R\&D gap is likely to heighten the technological challenges and economic costs associated with the long-term stabilization of atmospheric concentrations of $\mathrm{CO}_{2}$.

Utility restructuring is having an overall negative impact on private sector investments in energy R\&D. For example, while U.S. industries generally invests about $3.1 \%$ of annual sales revenues on R\&D, U.S. utilities, on average, devoted $0.3 \%$ of sales to R\&D in 1994; estimates indicate that this percentage has continued to decline since then. ${ }^{6}$ Similar trends are evident elsewhere in the OECD. Utilities in the UK have reduced their R\&D investments steadily over the past decade, to

\footnotetext{
${ }^{6}$ General Accounting Office (GAO) (1996). Changes in Electricity-Related R\&D Funding. GAO-RCED-
} 96-203, General Accounting Office, Washington, DC. 
a level that currently stands between $0.1 \%-0.3 \%$ of sales. Dutch utilities are reducing their R\&D investments from $0.7 \%$ to $0.6 \%$ of sales, with further decreases expected, while Norwegian utilities currently invest approximately $0.3 \%$ of sales in energy $R \& D$.

In terms of society's ability to stabilize atmospheric concentrations of $\mathrm{CO}_{2}$, it is important to note that certain forms of energy $R \& D$ are experiencing a much larger share of the reductions. $A$ recent utility industry journal article noted that utilities with plans to sell off generation assets will "naturally pull their funding for R\&D previously targeted to power production." 9 This shift away from advanced power generation $R \& D$ can be seen in actions taken by utilities in many countries.

For example, utilities in Italy and the Netherlands are no longer sponsoring new, large-scale technology demonstration programs and have terminated ongoing demonstration projects for advanced power system technologies, such as grid-connected photovoltaic systems, which can not be justified strictly on economic grounds. ${ }^{10}$ In the United States, Electric Power Research Institute's (EPRI) advanced power generation program (focusing on technologies such as fuel cells, coal gasification, advanced gas turbines, and renewable energy technologies) declined $66 \%$ over a 3 year period. " EPRI's renewable energy program, a subset of the advanced power generation program, saw its budget cut $45 \%$ in just two years. ${ }^{12}$

There is also mounting evidence that $R \& D$ time frames and perceptions of acceptable risk levels for energy R\&D sponsored by utilities are contracting due to heightened competition. For example, the time-horizon for British utilities' long-term R\&D projects has contracted from fiveto seven-years a decade ago, to less than three years now. It is estimated that in a fully competitive market $R \& D$ timeframes could be cut to one year for $R \& D$ sponsored by UK utilities. ${ }^{13}$ Under such circumstances, as one US utility research executive noted, the initiation of advanced power generation R\&D programs (e.g., fuel cells) would not be feasible. ${ }^{14}$

\footnotetext{
${ }^{7}$ International Energy Agency, Energy Technology Policy Office (1996). Submission to the International Energy Agency's Committee on Energy Research and Technology's Round Table on Greater Utility Competition and Its Impact on Industry and Government Technology R\&D Budgets and Priorities. Paris, France. 13 November.

${ }^{8}$ KEMA (The Netherlands) (1996). Summary of Corech/Eurelectric Discussion of R\&D in a Deregulated Market October 11, 1996. Paper presented to the International Energy Agency's Committee on Energy Research and Technology's Round Table on Greater Utility Competition and Its Impact on Industry and Government Technology R\&D Budgets and Priorities. Paris, France. 13 November.

${ }^{9}$ Jones, Cate. "R\&D continues to brace for a difficult future." Power. November/December 1998.

${ }^{10}$ Italian submission (1996). Paper and presentation to the International Energy Agency's Committee on Energy Research and Technology's Round Table on Greater Utility Competition and Its Impact on Industry and Government Technology R\&D Budgets and Priorities. Paris, France. 13 November.

The Netherlands' Economic Ministry. Greater Utility Competition in the Netherlands. Paper and presentation to the International Energy Agency's Committee on Energy Research and Technology's Round Table on Greater Utility Competition and Its Impact on Industry and Government Technology R\&D Budgets and Priorities. Paris, France. 13 November.

11 GAO, 1996.

${ }_{12}$ Electric Power Research Institute (EPRI). 1996. The Impact of Utility Industry Restructuring on Research for the Public Good. BR-107160. Electric Power Research Institute, Palo Alto, CA.

${ }^{13}$ Walker, J.A. and Riley, F.D. (1996). Utility Competition's Impact on Energy R\&D in the United Kingdom. Paper and presentation to the International Energy Agency's Committee on Energy Research and Technology's Round Table on Greater Utility Competition and Its Impact on Industry and Government Technology R\&D Budgets and Priorities. Paris, France. 13 November.

${ }^{14}$ Jones 1998.
} 
In this regard, Sweden's Vattenfall, the sixth largest utility in Europe, has completely reversed the composition of its $\mathrm{R} \& \mathrm{D}$ portfolio from $70 \%$ "corporate R\&D" (e.g., advanced power production) and $30 \%$ in the firm's "business units." Seventy percent of R\&D resources are now invested in the near-term R\&D needs at the "business unit" level. ${ }^{15}$ Vattenfall is doing away with its central "longer-term corporate $R \& D$ " in much the same way as countless energy firms eliminated their corporate R\&D laboratories in the late 1980s and early 1990s in an attempt to adjust to the demands of international economic liberalization. Energy R\&D investments are moving "downstream," closer to the consumer.

Utilities in deregulated markets are also directing more of their resources (including R\&D resources) to areas only tangentially related to energy. Utility companies are entering new businesses and reorienting $R \& D$ resources as well in areas such as telecommunications, home security, and integrated home energy management systems in an effort to offer new services that will allow them to maintain a strong customer base in an increasingly competitive environment. ${ }^{16}$ Similarly, firms that are planning to acquire new assets in a liberalized energy market setting often reduce their R\&D expenditures to build cash reserves needed to finance such purchases. ${ }^{17}$

The reductions in the support for energy $R \& D$ that are underway in the utility sector are also present in the oil and gas industry. The largest oil and gas companies in the U.S. (most of which are large multinationals) have reduced their investments in R\&D, by $43 \%$ on average, throughout the 1990s. ${ }^{18}$ Several factors have contributed to this trend, including consolidation in the oil and gas industries; the opening of several major upstream areas around the world, and the more extensive deployment of existing advanced exploration and production technologies. ${ }^{19}$ These overlapping drivers have had a dampening effect on energy R\&D in this industry. Since oil and gas prices are expected to remain stagnant or in decline in real terms for the foreseeable future, given slack demand and abundant supplies, firms have little incentive to expand their R\&D efforts.

Public Sector Energy R\&D. Currently, just nine OECD countries perform more than $95 \%$ of the world's public sector energy $R \& D$ and, consequently, nearly all of the world's long-term energy $R \& D .{ }^{20}$ Given the high concentration of energy R\&D capabilities in such a small number of industrialized nations, it is not an exaggeration to say that this small country set is defining the world's future energy choices through its energy R\&D investment decisions. It is also important to note that between 1985-1995, these nine energy R\&D intensive OECD countries each reduced their budgets for energy R\&D on average by more than $20 \%$ in real terms. In extreme cases, such

\footnotetext{
${ }^{15}$ KEMA 1996.

16 See Jones 1998 and Dooley 1998.

17 Jones, 1998.

${ }^{18}$ US Department of Energy, Energy Information Administration. Performance Profiles of Major Energy Producers, 1997. Washington, D.C. January 21, 1999.

${ }^{19}$ US Department of Energy, Energy Information Administration. Petrolium 1996: Issues and Trends. September 1997. Washington, D.C. DOE/EIA-0615.

${ }^{20}$ The countries are the United States, Japan, Germany, the Netherlands, United Kingdom, France, Italy, Canada, and Switzerland. The European Union, which is a major energy R\&D sponsor, is also regarded as an individual "country" in this paper, although its energy R\&D investments are not included among those of the nine countries listed here. Source; International Energy Agency, IEA Energy Technology R\&D Statistics: 1974-1995 (Paris: International Energy Agency, 1997).
} 
as those of Germany, Italy, and the United Kingdom, budgets were slashed by $70 \%$ or more over the same period. ${ }^{21}$

The scale of these reductions in energy $R \& D$ funding and the commonality of the funding cuts across countries make it worthwhile to examine the evolution of key countries' energy R\&D portfolios and to seek to explain the overall downward trend. In this section, we present preliminary findings from a major research effort underway at the Pacific Northwest National Laboratory to better understand the composition of the energy R\&D programs of these countries. $^{22}$ This ongoing research effort seeks to assess the adequacy of the industrialized world's energy R\&D programs, particularly in the light of the significant energy technology challenges that global climate change could soon pose. As of the end of 1998, in depth case studies of the United States, Japan, the European Union, Germany, and the Netherlands are near completion. In 1999, case studies for of Canada, France, Italy, Switzerland, and the United Kingdom will be completed thereby completing the survey of the major energy R\&D intensive nations.

Overall public sector investment levels in energy R\&D have declined over the past decade as the following data show ${ }^{23}$ :

- The US federal energy R\&D program has fallen by $26 \%$ over the period $1990-1997$, a decline of more than $\$ 1.2$ billion in real terms from the level in 1990 .

- The Japanese government's energy R\&D program declined $8.6 \%$ over the past three years (1996-1998), a real decrease of $\$ 226$ million. As a percentage of total public sector R\&D effort, energy R\&D has fallen from $19.9 \%$ in 1990 to $13.7 \%$ in 1998 .

- The German energy R\&D program has declined by $71 \%$ since 1990 , a funding reduction of $\$ 1.04$ billion.

- EU-sponsored energy R\&D has declined by $13 \%$ since 1984; as a fraction of the EU Framework Programme budget, energy R\&D's share has declined from $47 \%$ to $18 \%$ over the same period.

- The Netherlands' public energy R\&D support declined by $28 \%$ in real terms from 1985 to 1995. Support for energy R\&D has recovered somewhat between 1996-1997.

The trends in overall public budgets for energy R\&D tell an incomplete story, however. Figure 3 shows the energy R\&D portfolios of the five countries mentioned above by program area. The composition of these portfolios is, in many respects, as important as the overall funding levels in determining the range of future technological options. ${ }^{24}$

${ }^{21}$ International Energy Agency, IEA Energy Technology R\&D Statistics: 1974-1995 (Paris: International Energy Agency, 1997).

${ }^{22}$ This analysis was prepared using data obtained directly from country sources and avoiding data from third party sources such as the Paris-based International Energy Agency (IEA). The use of official country source data facilitated more accurate and more detailed analysis of energy R\&D trends. The use of country source data also enabled the conversion of all currencies into constant 1995 purchasing power parity (PPP) US dollars.

${ }^{23}$ These data are from JJ Dooley, PJ Runci, and EEM Luiten, "Energy R\&D in the Industrialized World: Retrenchment and Refocusing," Pacific Northwest National Laboratory Technical Report No. PNNL12061 (December 1998). This report summarizes the progress of this research program in 1998.

${ }^{24}$ The residual "Other" category in Figure 3 deserves explanation. For the US, this category amounts to nearly half of the US total energy R\&D effort and largely comprises the "basic energy sciences" research programs supported by the US Department of Energy's Office of Science (formerly the Office of Energy Research). These US programs explore fundamental aspects of the science that underpin energy technologies. In the other countries this "Other Energy R\&D" category accounts for programs focusing on systems and policy analysis, as well as some basic research, electric power transmission, distribution, and 
Figure 3 shows that national governments have sharply different priorities with regard to energy R\&D technology investment areas. For example, Japan devotes $66 \%$ of all public sector energy R\&D expenditures to nuclear fission programs, while the United States and the Netherlands devote a continually declining share-currently less than $8 \%$--of their energy R\&D resources to fission. ${ }^{25}$ Furthermore, although all of these nations have energy policies that place a very high priority on developing and deploying renewable energy and energy efficient technologies as a way of increasing their energy security and protecting the environment, only the Dutch government invests the majority of its energy $R \& D$ resources in these technology areas. An important observation that arises from this side-by-side analysis of public energy $R \& D$ expenditures is the large variance in the scale of government programs, from the United States' and Japan's expenditures of more than $\$ 2$ billion each, to the Netherlands' $\$ 137$ million expenditure. In fact, Japan's fission energy R\&D budget alone is larger than the sum of the Netherlands, EU, and German total energy R\&D budgets.

Significant changes are also occurring in the major energy R\&D program areas: fossil energy, energy efficiency, renewable energy, and nuclear energy.

Fossil Energy $R \& D$-Fossil energy $R \& D$ programs in industrialized countries no longer focus, as they did a decade or more ago, on research to locate and characterize new fossil energy resources and to develop new methods of cheaply extracting these resources. To a large extent, fossil energy R\&D programs are also moving away from the development of "clean coal technology" programs designed to improve the efficiency and cleanliness of fossil fuel combustion. The beginning of a potentially significant transition in fossil energy research programs is now discernible, wherein programs are seeking to develop zero carbon dioxide emitting fossil fuel technologies. Amid this transition, technologies that are receiving increasing emphasis include methods to "decarbonize" fossil fuels, programs to develop fuel cells capable of making use of the resulting hydrogen-rich fuel streams, and methods to sequester carbon dioxide. Another noteworthy trend is the expansion of fossil fuel research efforts to investigate the potential for developing new, plentiful, and relatively clean hydrocarbon resources such as methane hydrates and coal bed methane reservoirs. Although these non-conventional fossil energy R\&D programs are currently small, their emergence signals an expansion of the concept of fossil fuels and an expectation of the continued viability of fossil fuels, even under greenhouse gas constraints, well into the next century. The Netherlands and Japan, for example, have had long-standing research programs examining the efficacy of new fossil energy technologies such as carbon sequestration. Of the industrialized countries surveyed, Japan is the largest supporter of these advanced fossil energy research programs (e.g., carbon sequestration, methane hydrates). ${ }^{26}$

Renewable Energy $R \& D$ - In recent years, the focus of industrialized countries' renewable energy $R \& D$ programs has become ever more concentrated in the area of solar photovoltaics. Wind energy technology research also receives significant support although it appears that the primary objective of wind energy R\&D programs is on technology deployment and commercialization,

storage R\&D programs. Other nations do not seem to fund these "basic energy sciences" on a scale comparable to that of the United States.

${ }^{25}$ At this point in this research effort, these comparisons are rough estimates. This research project is still collecting and standardizing the data from country sources. For example, the US "fission energy R\&D" program might not include US funds for research covered in the other nation's fission R\&D programs such as those used for the geologic disposition of radioactive waste.

${ }^{26}$ Monastersky, Richard. "The Ice that Burns: Can methane hydrates fuel the $21^{\text {st }}$ century?" Science News. November 14, 1998 
Figure 3: Public Sector Energy R\&D Portfolios
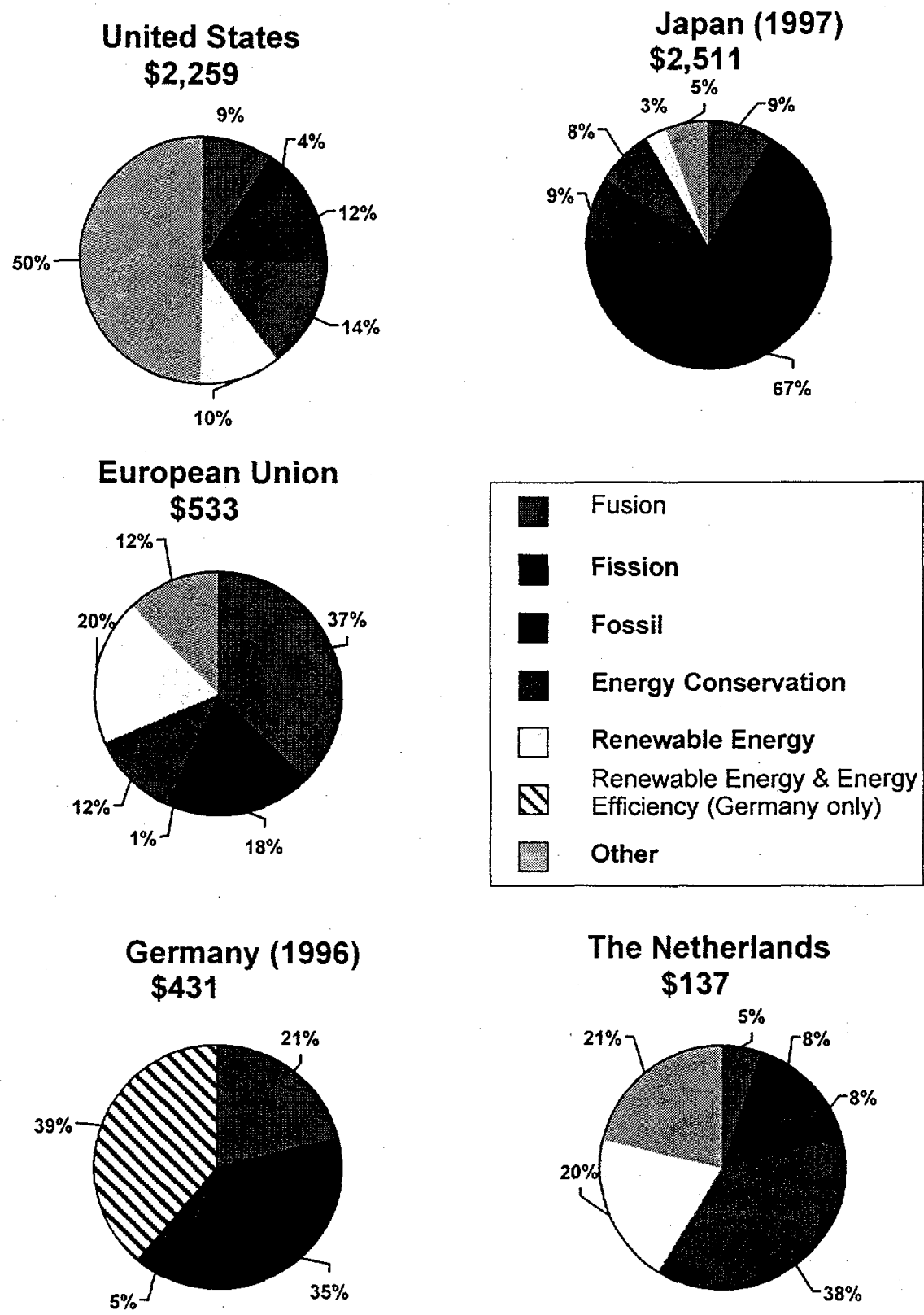

rather than on the development of new systems and components that would fundamentally improve the efficiency or economics of wind power systems. Interestingly, Japan continues to devote significant resources to renewable energy technology programs that no longer receive funding from other industrialized countries such as wave/ocean power and waste-to-energy systems. Also, the Japanese government funds a relatively large amount of geothermal research given the abundance of geothermally active sites in Japan. Perhaps the most significant trend in 
renewable energy research is the relatively flat budgets of these programs throughout the course of the $1990 \mathrm{~s}$, a decade that saw increasing rhetoric from national governments pledging to do their best to reduce carbon dioxide emissions through, in part, the increased use of renewable energy systems.

Energy Efficiency -Funding for energy efficiency programs has experienced the most consistent growth of all technology areas. In the United States, for example, public energy efficiency R\&D has increased by $53 \%$ since 1990 . Similarly, while Germany's consolidated energy efficiency and renewable $R \& D$ budget has grown only slightly over the past decade, its percentage of the total energy R\&D budget has grown since 1985 from $9 \%$ to $39 \%$. The Netherlands' efficiency programs have also grown steadily, now accounting for some $38 \%$ of the Dutch public energy $R \& D$ budget. Industrial energy efficiency programs appear to be receiving preference for $R \& D$ funds over buildings or transportation-related energy efficiency programs. This preference for industrial energy efficiency R\&D likely reflects both a desire to improve competitiveness and to protect the environment. $^{27}$

Nuclear Energy $R \& D$ - The future of nuclear energy and related technologies is in a period of uncertainty in many countries. Many nations are decidedly shifting an ever-larger share of their fission energy $R \& D$ programs away from the development of new reactors and components to focus on research activities concerned with the nuclear fuel cycle, waste disposal, and reactor decommissioning. In Germany and the United States, for example, the fission research budgets have fallen in real terms by more than $90 \%$ over the past decade. With respect to fusion research, Congress' withdrawal of support for U.S. participation in the International Thermonuclear Experimental Reactor (ITER) project and the change in focus of the domestic program from "fusion energy technology development" to "fusion energy sciences" indicates that the commercial availability of fusion energy is still on the distant horizon.

With regard to future energy $R \& D$ scenarios, it is important to note that despite major differences across countries in political culture and choices of policy instruments, countries share an assumption that greater energy efficiency will carry them a significant part of the way toward realizing major carbon emissions reductions in the future. For example in the United States, some have argued that major emissions reductions could be achieved at no cost through the aggressive deployment of new energy efficiency technologies and the creation of an international carbon permit trading regime. ${ }^{28}$ This policy trend raises questions about the prospects for future government support for new, advanced energy technology programs that will be needed to stabilize atmospheric $\mathrm{CO}_{2}$ concentration over the next century.

There is also mounting evidence that the ongoing deregulation of the energy industries in many countries is exerting downward pressure on energy R\&D activities, particularly in the private sector. $^{29}$ While deregulation often leads to positive outcomes such as lower energy prices and more choice for consumers, the competitive dynamics it introduces also heightens managers' and

\footnotetext{
${ }^{27}$ See Bundesministerium fur Bildung, Wissenschaft, Forschung, und technologie, 4. Programm Energieforschung und Energietechnologien (Bonn: BMBF, 1997), p. 10; European Commission, EC Research Funding (Luxembourg: Office for Official Publications of the European Communities, 1996), p.15.

${ }^{28}$ Interlaboratory Working Group. 1997. Scenarios of U.S. Carbon Reductions: Potential Impacts of Energy-Efficient and Low-Carbon Technologies by 2010 and Beyond (Berkeley, CA: Lawrence Berkeley National Laboratory and Oak Ridge, TN: Oak Ridge National Laboratory), LBNL-40533 and ORNL-444, September (URL address: http://www.ornl.gov/ORNL/Energy_Eff/CON444), Executive Summary.

${ }^{29}$ Dooley, 1998.
} 
shareholders' sensitivity to short-term market performance indicators. The pressures on private sector energy firms to reduce costs increasingly compel them to reduce their levels of R\&D expenditure and to focus their remaining $R \& D$ investments on shorter-term, product-oriented projects. By "privatizing" the governance of the energy industries through deregulation, governments redefine the roles of the public and private sectors in providing energy services to the public. Although privatization may bring higher levels of economic efficiency in the energy industries, those gains may compromise the ability to take a long view with regard to the energy future and to invest accordingly in energy R\&D.

We conclude this overview of trends within the energy R\&D programs of the leading energy $R \& D$ intensive industrialized nations with the following summary points:

- In stark contrast to overall national $R \& D$ (combined public and private sector $R \& D$ in all areas) which has flourished over the past decade, national energy $R \& D$ efforts have not experienced significant growth over the past decade. In the nations surveyed, the dominant trend has been toward significant reductions in publicly and privately funded energy R\&D. For the public sector, energy $R \& D$ as a percent of total public sector $R \& D$ and as a percent of gross domestic product has also been in decline in all of these nations. Where data are available, it is evident that private sector energy $R \& D$ investment is also in decline.

- Budgetary pressures, energy deregulation, and the perceived lack of an "energy crisis" are likely to dampen government energy $R \& D$ budgets for the foreseeable future. In the absence of major shifts in the world energy outlook, government energy R\&D investments appear unlikely to be restructured and expanded in a way that is optimal for developing the technologies needed in the middle to long term to avoid global climate change.

- The current turmoil in private sector energy R\&D programs brought about in large measure by the push to deregulate the energy industries will continue to place downyard pressure on private sector investments in longer term energy R\&D.

- Public energy R\&D is evolving in important ways from the perspective of climate change. Research programs aimed at the development of fuel cells, hydrogen infrastructure technologies, and carbon capture and disposal technologies represent a small but growing percentage of government energy R\&D investment.

- There is an increasing gap between governments' aspirations to curb carbon dioxide emissions, as expressed in policy statements, and their funding commitments to energy R\&D. Many countries appear to have adopted a de facto policy of relying on the further deployment of existing energy efficiency technologies, fuel switching and emissions trading as the primary means of reducing carbon dioxide emissions. While these efforts are important and necessary, they are, in and of themselves, insufficient to address the climate change problem. ${ }^{30}$

\section{Conclusions}

The small group of OECD nations that fund the vast majority of the world's energy R\&D are defining the world's future energy technology choices. Unless additional countries mount significant efforts to develop energy $R \& D$ programs, the energy research currently underway in the OECD will define the energy technology solutions with which the world will be equipped in the next century to address climate change. Considering the long lead times between initial investments in the development of new technologies and the availability of new technologies for commercial deployment, those technologies that exist today and that are already in the R\&D

\footnotetext{
${ }^{30}$ National Laboratory Directors, Technology Opportunities to Reduce U.S. Greenhouse Gas Emissions (October 1997), p. xiii.
} 
"pipeline" are those that will be available over the next few decades to meet global energy challenges. Declining energy R\&D budgets in leading industrialized nations bespeak a narrowing range of future technological options.

That said, energy technology programs that could have significant impacts in addressing climate change are starting to emerge. For example, the beginning of a potentially significant transition in fossil energy research programs is now discernible, wherein programs are seeking to develop zero carbon dioxide emitting fossil fuel technologies. Key technologies that are beginning to receive budget preference include methods to "decarbonize" fossil fuels, fuel cells, and methods to dispose of or sequester carbon dioxide wastes. The total amount of resources committed to these technology areas is currently small, however.

The observed changes in the makeup of national energy R\&D portfolios have major implications for three additional aspects of energy technology development as it relates to efforts to meet the challenge of climate change. Each of these is discussed below.

The scale of the world's energy $R \& D$ enterprise is contracting. The challenge posed by climate change demands continuing advancements in energy technologies over the course of the next century. The continuing reductions in the scale of national energy $R \& D$ programs and the apparent shift to shorter term research suggests that the world is entering the next century with fewer energy R\&D options than would be the case had more robust and sustained energy R\&D funding levels been maintained. The drastic reductions that have taken place in key countries such as Germany and the United Kingdom have seriously stunted the research capabilities of these countries to carry out energy supply R\&D on a scale that is "commensurate in scope and scale with the challenges and opportunities of the twenty-first century.

Collaborative R\&D between and among OECD countries is constrained by shrinking public energy $R \& D$ investments. In an era of greater fiscal discipline and shrinking government spending, public-private and international $R \& D$ cost sharing is increasingly popular among policy makers in major industrialized countries. The Japanese fast breeder reactor program and the International Thermonuclear Experimental Reactor (ITER) are examples of energy technology areas where international collaboration and cost-sharing have succeeded in sustaining "big science" projects. Yet, in countries such as the U.S., the U.K., and Germany, deep energy R\&D budget cuts may be having the opposite effect. As both public and private sector energy R\&D budgets contract, pressure often intensifies to focus remaining resources "downstream" on shorter-term, applied research aimed at the development of commercial technologies rather than on longer-term and basic research. The proprietary nature of the downsteam end of the technology innovation process imposes disincentives for international collaboration. Since responding to climate change will require both new energy technologies and international collaboration to that end, the shrinking of government $R \& D$ budgets may inflict double damages by precluding both of these.

Collaborative $R \& D$ between $O E C D$ and developing countries is constrained by shrinking public energy $R \& D$ investments. In the absence of a significant change in the current incentive structure and in the scale of OECD countries' energy R\&D efforts, it is unlikely that collaborative energy R\&D programs involving OECD and developing countries will expand substantially. While the energy technology imperatives of climate change argue in favor of long-term collaboration and

\footnotetext{
${ }^{31}$ Holdren, John, et. al. 1997. Federal Energy Research and Development for the Challenges of the Twenty-first Century. Report of the Energy Research and Development Panel of the President's Committee of Advisors on Science and Technology. September 30, 1997. Washington, D.C.
} 
capacity-building between OECD and developing countries, the shorter-term imperatives of the market currently appear to be taking precedence.

The challenge is for industrialized countries to do more than deploy existing energy technologies and transfer turnkey energy systems to the developing world. Meaningful response to climate change demands that today's energy R\&D performing nations adopt the long view, embarking on efforts to engage major developing countries as partners in the climate change solution. Although shorter-term incentives will tempt OECD countries to regard major developing countries as future markets for energy technology exports, the danger of this approach is that it may contain the seed of its own destruction. Economic, political, and security considerations are likely to prompt developing countries to avoid deepening dependence on imported energy technologies. The alternatives for these countries will be either to continue to grow using current generation energy technologies, or to attain a higher level of technological self-sufficiency. Global environmental well-being argues in favor of efforts to extend the world's energy R\&D capabilities by helping developing countries to become significant contributors of energy technology. 